УДК 81 '373

DOI https://doi.org/10.26661/2414-9594-2020-2-17

\title{
КОГНІТИВНА ІНТЕГРАЦІЯ ДЕМІНУТИВІВ
}

\author{
Романенко О. П. \\ аспірантка кафедри германської і фіно-угорської філологї \\ імені професора Г. Г. Почепцова \\ Київський національний лінгвістичний університет \\ вул. Велика Васильківська, 73, Київ, Украӥна \\ orcid.org/0000-0003-4490-5533 \\ donnaolga@ukr.net
}

Ключові слова: ментальні простори, метафорична модель, семантикокогнітивний формант, метафора, бленд.
У статті розглянуто процес концептуальної інтеграції, який базується на основі об'єднання теорії концептуальної метафори та теорії концептуальних просторів. Досліджено ментальні простори як концептуальні структури оперативної пам'яті людини, що виникають в іiі свідомості в момент породження мовлення. Ментальні простори перебувають між собою в когнітивних зв'язках, тому концептуальні структури можуть використовуватися для утворення інших концептуальних структур, які виникають в інтегрованих просторах. Ці простори, комбінуючись, утворюють бленд, який є не просто набором елементів початкових просторів, а новою унікальною структурою. Розглянуто просторові моделі, що конструюються на основі метафори, яка актуалізує ті ознаки та смисли, що не є головними і суттєвими для прямого значення слова, але є стійкими у свідомості мовців. Зазначено, що в основі метафоризації, за теорією концептуальної метафори, лежить процес взаємодії між структурами знань двох доменів: сфери-джерела і сфери-мішені. Чим детальніше структурована понятійна сфера-джерело, тим більше номінативних можливостей у понятійної сфери-донора. Особливу увагу зосереджено на дослідженні процесу метафоричного моделювання та ознак метафоричної моделі А.П. Чудінова Творчо опрацьовано семантико-когнітивні форманти, досліджені у роботах Ю.В. Кравцової, що базуються на типах метафоричної мотивації. Представлено певні аспекти метафоричного моделювання демінутивів, що відбуваються через вербалізацію корелятивних в асоціативному плані понять, утворюючи метафоричні моделі. Метафорична модель містить вихідну і нову поняттєві сфери метафоричної проєкції та семантико-когнітивний формант, який інтегрує ці сфери за схожою рисою. Розглянуто метафоричні моделі демінутивів, які утворюються за перенесення компонента значення твірного слова на похідне слово, тобто під час взаємодії компонента значення одного концептуального простору зі значенням іншого концептуального простору, у результаті чого утворюється бленд, демінутивна одиниця. Детально досліджено метафоричну модель демінутива «котик». 


\title{
COGNITIVE INTEGRATION OF DEMINUTIVES
}

\author{
Romanenko O. P. \\ Postgraduate Student at Professor G. G. Pocheptsov Department \\ of Germanic and Finno-Ugric Philology \\ Kyiv National Linguistic University \\ Velyka Vasylkivska str., 73, Kyiv, Ukraine \\ orcid.org/0000-0003-4490-5533 \\ donnaolga@ukr.net
}

Key words: mental spaces, metaphorical model, semantic-cognitive formant, metaphor, blend.

\begin{abstract}
The article considers the process of conceptual integration, which is based on the combination of the theory of conceptual metaphor and the theory of conceptual spaces. Mental spaces are studied as conceptual structures of a person's memory, which arise in his consciousness at the moment of speech generation. Mental spaces are cognitively interconnected, that's why conceptual structures can be used to form other conceptual structures that arise in integrated spaces. These spaces form a blend, which is not just a set of elements of the original spaces, but a new unique structure. Spatial models are constructed on the basis of a metaphor that actualizes those features and meanings that are not the main and essential for the direct meaning of the word, but are stable in the minds of speakers. It is noted that the basis of metaphorization, according to the theory of conceptual metaphor, is the process of interaction between the knowledge structures of two domains: the source sphere and the target sphere. Particular attention is paid to the study of the process of metaphorical modeling and features of the metaphorical model of Chudinov A. P. Creatively are developed semantic-cognitive formants, studied in the works of Kravtsova Yu. V. Certain aspects of metaphorical modeling of diminutives, which occur through the verbalization of correlative concepts in the associative plan and forming metaphorical models, are presented. The metaphorical model contains the new conceptual area of metaphorical projection and the semantic-cognitive formant, which integrates this area according a similar feature. Metaphorical models of diminutives are formed, when the component of the meaning of a forming word is transferred to a derived word, when the component of the meaning of one conceptual space interacts with the meaning of another conceptual space, creating a blend, a diminutive. The metaphorical model of the diminutive "little cat" is presented in detail.
\end{abstract}

Постановка проблеми. Спрямованість сучасних конгітивних досліджень (М. Джонсон, Дж. Лакофф, О.О. Селіванова) на вивчення нових сфер застосування концептуальної метафори актуалізували нові дослідження іiі моделей (А.П. Чудінов, В.М. Телія) у результаті когнітивного процесу концептуальної інтеграції (Ж. Фоконьє, М. Тернер). Традиційна двопросторова модель метафоричного проектування, що заснована на взаємодії двох структур знань - когнітивної структури «джерела» і когнітивної структури «мети» (М. Джонсон, Дж. Лакофф), засвідчує необхідність подальшого розроблення цієї проблематики, особливо під час аналізу демінутивних одиниць, що й зумовлює іiі актуальність.

Мета статті - розкрити перебіг побудови метафоричних моделей демінутивів, спираючись на процес когнітивної інтеграції демінутивів.
Об'сктом дослідження $є$ когнітивна інтеграція, а предметом - метафоричні моделі демінутивів, що були досліджені за допомогою методів аналізу, які включають аналіз словникових дефініцій, метод концептуального аналізу 3 метою моделювання типів концептуальних метафор, а також методику встановлення метафоричних імплікацій (асоцітивних зв'язків) та інструментарій теорії концептуальної метафори і теорії концептуальних просторів.

Виклад основного матеріалу дослідження. Розглядаючи поняття мотивації, що інтерпретує ономасіологічну структуру слова та розкриває когнітивні механізми творення вторинно-номінованих одиниць, передовсім демінутивних, окрему увагу слід зосередити на вивченні асоціативно-термінального типу мотивації (О.О. Селіванова) 
демінутивів, що відображає процес концептуальної інтеграції (Ж. Фоконьє, М. Тернер), який базується на основі об'єднання положень теорії концептуальної метафори (М. Джонсон, Дж. Лакофф) та теорії концептуальних просторів (Ж. Фоконьє). Теорія концептуальної метафори (М. Джонсон, Дж. Лакофф) не повністю відображає процес об'єднання двох смислів під час утворення нових одиниць. На думку О.С. Кубрякової, інтеграція смислів відбувається за їх природної сумісності, а для цього необхідний когнітивний зв'язок [1, с. 455].

Поняття когнітивного зв'язку розглядають, як правило, у зв'язку з так званими ментальними просторами - концептуальними структурами оперативної пам'яті людини, що виникають в іiї свідомості в момент породження мовлення [2, с. 40]. Прикладом ментального простору може бути будь-яка концептуальна структура, активація якої зумовлює вживання мовної одиниці в іiі регулярному значенні. Ментальні простори перебувають між собою в когнітивних зв'язках, тому концептуальні структури можуть використовуватися для утворення інших концептуальних структур, які виникають в інтегрованих просторах [2, с. 41]. На думку Ж. Фоконьє та М. Тернера, необхідною умовою для об'єднання просторів є наявність загальних, тобто спільних, елементів у вихідних просторах

Дж. Лакофф [3, с. 172-173] висловлює думку, що ментальні простори можуть включати ментальні сутності або структуруватися когнітивними моделями, а також вони пов'язані з іншими просторами такими структурами, які Ж. Фоконьє називає конекторами. Ментальні простори здатні розширюватися, тому в процесі когнітивної діяльності до них приєднуються інші сутності.

Схема процесу концептуальної інтеграції, що була запропонована Ж. Фоконьє і М. Тернером, має своє теоретичне підгрунтя для ментальних просторів. У межах цієї схеми два традиційні вхідні простори доповнюються двома додатковими: родовим простором (generic space) і вихідним змішаним простором (blended space) [4, c. 47].

При цьому Д.М. Кірєєва, досліджуючи праці В. Еванса [5], зазначає, що два вхідні простори містять прототипічні риси концептів, які беруть участь у процесі інтеграції. Родовий простір $\epsilon$ медіатором між вхідними просторами і містить атрибути концептів, наявні в обох вхідних просторах. Конектори утворюються за допомогою такої концептуальної операції, яка ідентифікує міжпросторові аналоги у вхідних просторах.

У моделі Ж. Фоконьє і М. Тернера [4, с. 47] ці простори, комбінуючись, утворюють незалежний вихідний змішаний простір або бленд, який становить комплексну інтегровану структуру. Тому бленд - це не просто набір елементів початкових просторів, а цілком нова унікальна структура, що має специфічні елементи, які суттєво відрізняються від елементів початкових структур, що входять до нього [4, с. 42]. Але не всі елементи й відношення проєктуються із вхідних просторів у бленд, тобто відбувається вибіркова проєкція.

На цій підставі у змішаному просторі формується нова (еменджентна) структура, що генерується через комбінування, у результаті якого отриманий змішаний вихідний простір співвідноситься з інформацією в довготривалій пам'яті, а також через розвиток, тобто подальше уявне моделювання і формування змішаного концепту. Під час комбінування здійснюється проєкція вмісту кожного вхідного простору у вихідний змішаний простір [4, с. 48].

У цьому разі варто враховувати те, що до процесу концептуальної інтеграції залучені особистісне розуміння та асоціації, якими володіє мовець. Отже, після встановлення зв'язків між знаннями мовця різних елементів вхідних просторів можна будувати можливі просторові моделі.

Просторові моделі конструюються на основі тотожності, а отже, на основі метафори. У метафорі актуалізуються ті ознаки та смисли, які не є головними і суттєвими для прямого значення слова, але $\epsilon$ стійкими у свідомості мовців. Образні асоціації утворюють мотивувальну основу для виникнення конотацій і $є$ мотивувальною базою для метафоричного перенесення [4, с. 49].

Метафора не лише формує уявлення про об'єкт, а й зумовлює спосіб мислення про нього, маючи здатність визначати, створювати, тобто моделювати структуру реальності [7, с. 94-96].

С.А. Жаботинська вважає, що в перебігу творення метафори спрацьовує когнітивний механізм, призначений для обробки інформації про абстрактні об'єкти, які не сприймаються перцептивно, а підлягають операції порівняння 3 об'єктами конкретними, які мають перцептивну основу [8, с. 3-6]. Це визначення метафори співвідноситься 3 розумінням метафори у Дж. Лакоффа, який іiі визначає як «когнітивний інструмент для осмислення абстрактних понять» [9, с. 244]. В основі метафоризації, за теорією концептуальної метафори, лежить процес взаємодії між структурами знань двох доменів: сфери-джерела і сфери-мішені. Вихідною тезою теорії концептуальної метафори $є$ положення про те, що метафора належить не до рівня суто мовної техніки, а до рівня мислення й діяльності [9].

Поняття процесу метафоризації тісно пов'язане 3 процесом метафоричного моделювання, тобто засобом уявлення й оцінки певного фрагменту дійсності через абсолютно іншу поняттєву сферу [10, с. 110]. За А.П. Чудіновим «метафоричні моделі є певними концептуаль- 
ними матрицями, схемами зв'язку між різними понятійними сферами, складовими різних моделей світу», що формуються на «типовому співвідношенні семантики, яка перебуває у відношеннях безпосередньої мотивації вторинних і первинних значень» $[10$, с. 7]. Ця теза збігається із семантико-когнітивним підходом до аналізу метафори у Ю.В. Кравцової, де метафорична модель - «це схема вербалізації корелятивних в аналого-асоціативному плані понять, в основі якої закладена метафорична мотивація» [11, с. 47]. Чим детальніше структурована понятійна сфера-джерело, чим більше номінативних можливостей у понятійної сфери-донора, тим більшим $є$ потенціал метафоричної моделі.

У своєму дисертаційному дослідженні Л.Г. Сутуліна, спираючись на дослідження А.П. Чудінова, інтерпретує метафоричну модель як «бінарну когнітивну сполуку, яка утворена шляхом ментальної операції метафоричної проєкції поняттєвих елементів із царини джерела на царину мети та виражається формулою $\mathrm{X}-$ це У» $[12$, c. 8$]$.

Ознаками метафоричної моделі за А.П. Чудіновим [10], що доводять валідність цієї формули, є:

- вихідна понятійна сфера (ментальна сфера-джерело, сфера-донор), тобто семантична сфера, до якої належать слова в первинному значенні [10]. Наприклад, у демінутива «котик» вихідна понятійна сфера - це «тварина» (кіт);

- нова понятійна сфера (ментальна сфера-мішень, денотативна зона, реципієнтна сфера, напрям метафоричної експансіі), тобто в термінах теорії регулярної багатозначності семантична сфера, до якої відносяться слова в переносному значенні [10] . У нашому прикладі новою понятійною сферою у демінутива «котик» $є$ «дитина»;

- типові для даної моделі сценарії, які відображають найбільш характерні для вихідної понятійної сфери послідовності ситуацій [10]: наприклад, сценарій «тварина» передбачає догляд за нею, ii харчування і т. п.;

- фрейми, що відносяться до даної моделі, кожен 3 яких є фрагментом мовної картини світу, що структурує відповідну понятійну (концептуальну) сферу [10] . За визначенням В.З. Дем'янкова, фрейм - «це одиниця знань, що організована довкола певного поняття, це - структура даних для представлення стереотипної ситуації» [13, с. 188]. Фреймами понятійної сфери «тварина» є дикі тварини, свійські тварини;

- типові слоти, що становлять фрейм, тобто елементи ситуації, які включають певну частину фрейма, певний аспект його конкретизації [10]. Наприклад, фрейм «свійські тварини» містить такі слоти, як кіт, собака, корова та ін.;
- компонент, що пов'язує первинні і вторинні значення одиниць, що позначає дана модель, тобто підстава для метафоричного конструювання відповідних понятійних сфер, причина, через яку понятійна структура сфери джерела виявляється відповідною для позначення елементів зовсім іншої сфери [10]. Підставою для метафоричного конструювання понятійних сфер «тварина» та «дитина» є маленький розмір, залежність від дорослого чи господаря, беззахисність, потреба в молоці та ін.

Семантико-когнітивні форманти, що базуються на типах метафоричної мотивації, досліджує у своїх роботах Ю.В. Кравцова. Семантико-когнітивними формантами, або компонентами, що інтегрують різні сутності за певною схожою рисою, можуть бути форма, колір, звук, стан, оціночність, функційність та ін. [14, с. 90-91].

Виходячи із цього, метафоричною моделлю демінутива «котик» $є$ «Тварина - Людина», де зоонім $\epsilon$ корелятом метафори. До цієї метафоричної моделі належать також демінутиви «перепеличка», «ласочка», «зайчик», «лебідонька», у яких когнітивним формантом є оціночність.

Метафоричною моделлю демінутивів «носик» та «зубок» $є$ «Частина тіла людини - Частина рослини», бо ніс у людини подібний за формою до носика у рослин, а зуб у людини подібний за формою до зубка у рослин (часника), семантико-когнітивним формантом цих демінутивів $є$ форма.

Прикладами метафоричної моделі «Артефакт Частина рослини» є пари слів стріла - стрілка, чашка - чашечка, човен - човник, де форма «артефактів» стріла, чашка, човен є подібною до форми «частин рослини»: стрілки, чашечки, човника, тобто є їхнім формантом [15].

Проаналізуємо значення іменника «нога»- це «одна 3 двох нижніх кінцівок, орган руху й опори тварин і людини», компонент значення зазнає трансформації значення порівняно 3 іменником 3 демінутивним суфіксом ніжка - це «стебло рослини в розчленованих номінаціях або опора, основа чогонебудь». За Н.Ф. Клименко йдеться про метафоричне переосмислення компонента значення іменника «нога» у разі, коли компонент значення «опора» твірного слова (нога) переноситься на похідне слово (ніжка), тобто компонент значення одного концептуального простору «частина тіла людини» вступає у взаємодію зі значенням другого концептуального простору «частина рослини». У результаті цієї інтеграції утворюється бленд, демінутивна одиниця «ніжка», що містить у собі компонент значення «опора», але не у людини, а у рослини [15]. Метафоричною моделлю демінутива ніжка є «Частина тіла людини - Частина рослини», а семантико-когнітивним формантом $\epsilon$ форма.

Повертаючись до процесу побудови концептуальної інтеграції, розглянемо, наприклад, 


\begin{tabular}{|c|c|c|}
\hline \multirow{3}{*}{ 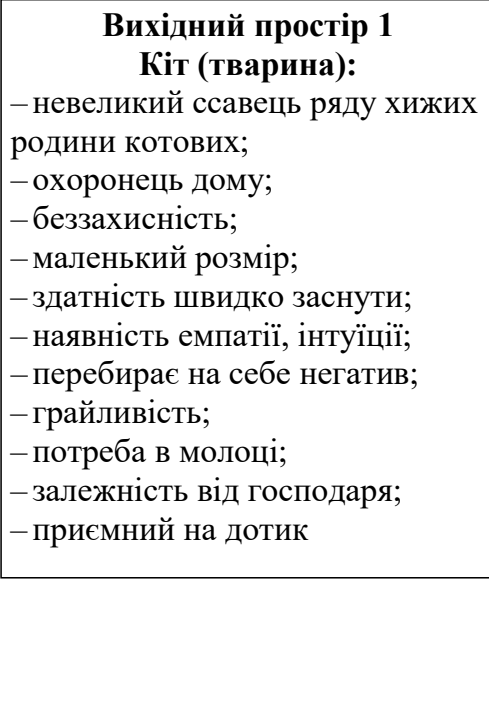 } & $\begin{array}{l}\text { Загальний простір } \\
\text { - маленький розмір; } \\
\text { - залежність від } \\
\text { дорослого\господаря; } \\
\text { - беззахисність; } \\
\text { - потреба в молоці; } \\
\text { - приємний на дотик }\end{array}$ & \multirow{2}{*}{ 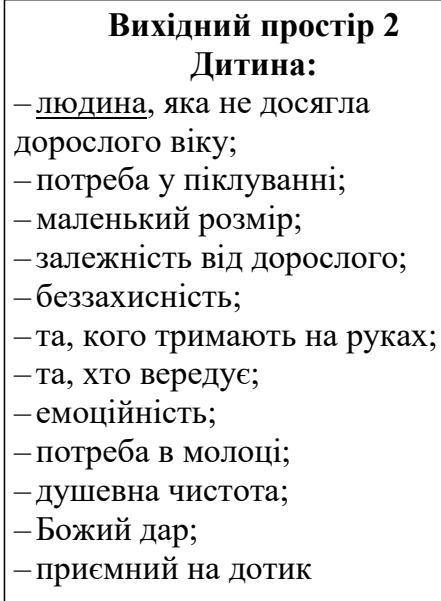 } \\
\hline & \multirow{2}{*}{$\begin{array}{l}\text { Змішаний простір (бленд) } \\
\begin{array}{c}\text { Котик } \\
\text { (метафора) }\end{array} \\
\text { - маленький розмір; } \\
\text { - залежність від } \\
\text { дорослого/господаря; } \\
\text { - беззахисність; } \\
\text { - потреба в молоці; } \\
\text { - приємний на дотик. } \\
\text { - вираження ніжності і любові }\end{array}$} & \\
\hline & & \\
\hline
\end{tabular}

Рис. 1. Схема моделі змішаного простору «Тварина - Дитина»

демінутив «котик» 3 уривку української колискової пісні: «Ой ну, котик, котино, засни моя дитино» (рис. 1). Так, у демінутиві «котик» (в якому ономасіологічна ознака «кіт» та ономасіологічний базис - ик) вихідним простором $\epsilon$ «тварина», а саме кіт. Атрибути вихідного простору 1 «Тварина» (невеликий ссавець ряду хижих родини котових, охоронець дому, беззахисність, маленький розмір, здатність швидко заснути, наявність емпатії, грайливість, потреба в молоці та ін.) співвідносяться 3 атрибутами вихідного простору 2 «Дитина» за зовнішніми ознаками (мініатюрність, приємність на дотик) та загальними характеристиками (залежність від дорослого чи господаря, беззахисність, потреба в молоці), утворюючи загальний простір, у який у процесі метафоричного конструювання проєктуються спільні ознаки 3 обох просторів, такі як маленький розмір, залежність від дорослого чи господаря, беззахисність, потреба в молоці, приємний на дотик. Ознаки із загального простору проєктуються в бленд, створюючи нову концептуальну структуру «котик». У цьому бленді здійснюється концептуальна інтеграція двох вихідних ментальних просторів, що запозичує семи із загального простору, утворюючи нову структуру 3 новими ознаками, такими як, наприклад, «вираження ніжності і любові», що конструюються в бленді і додають абсолютно нові, але зрозумілі інференції та виступають засобом репрезентації оцінного значення.

Висновки. Підсумовуючи, зазначимо, що процес когнітивної інтеграції - це основа для конструювання метафоричного значення демінутивів, що моделюється через часткові відповідності між вихідними ментальними просторами і вибірковою проєкцією атрибутів кожного $з$ вихідних просторів у новий змішаний простір (бленд), де відбувається виникнення емерджентної (нової) структури.

Метафоричне моделювання демінутивів відбувається через вербалізацію корелятивних в асоціативному плані понять, тобто за допомогою зв'язку між поняттєвими сферами, що утворюють метафоричні моделі: «Тварина - Людина», «Артефакт - Частина рослини», «Частина тіла людини - Частина рослини». Метафорична модель містить вихідну і нову поняттєві сфери метафоричної проєкції та семантико-когнітивний формант, який інтегрує ці сфери за схожою рисою, такою як форма, колір, звук, стан, оціночність, функційність та ін.

\section{ЛІТЕРАТУРА}

1. Кубрякова Е.С. Язык и знание. На пути получения знания о языке: части речи с когнитивной точки зрения. Роль языка в познании мира. Москва, 2004.

2. Бабина Л.В. Вторичная репрезентация концептов в языке : дисс. ... док. филолог. Тамбов, 2003. 341 с.

3. Лакофф Дж. Женщины, огонь и опасные вещи: Что категории языка говорят нам о мышлении. Москва, 2004.

4. Fauconnier G., Turner M. The way we think: conceptual blending and the mind's hidden complexities. New York, 2002. 
5. Киреева Д.М. Происхождение теории концептуальной интеграции. Мир науки, культуры, образования. 2012. № 4(35). С. 78-80.

6. Маслова В.А. Лингвокультурология : учебное пособие. Москва : Академия, 2001. 208 с.

7. Метафора: в языке и тексте. Москва : Наука, 1988. 176 с.

8. Жаботинская С.А. Концептуальная метафора: процедура анализа для множественных данных. Актуальні проблеми менталінгвістики : зб. ст. за матер. VII Міжнар. наук. конф. Черкаси : ЧНУ ім. Б. Хмельницького, 2011. С. 3-6.

9. Лакофф Дж., Джонсон М. Метафоры, которыми мы живем / под ред. и с предисл. А.Н. Баранова. Москва, 2004.

10. Чудинов А.П. Россия в метафорическом зеркале: когнитивное исследование политической метафоры (1991-2000) : монография ; Урал. гос. пед. ун-т. Екатеринбург, 2001. 238 с.

11. Кравцова Ю.В. Метафорическая мотивация и ее основные типы (на материале русской художественной метафорики). Наукові праці. Серія «Філологія. Мовознавство». 2014. Вип. 209. Т. 221. C. $46-51$.

12. Сутуліна Л.Г. Метафорична модель реальне-ірреальне у наративній структурі іспанських романів-спогадів XX-XXI століття : дис. ... канд. філолог. наук. Київ, 2016. 223 с.

13. Краткий словарь когнитивных терминов / под общей редакцией Е.С. Кубряковой Москва, 1996. $245 \mathrm{c}$.

14. Кравцова Ю.В. Методологические основы семантико-когнитивного исследования метафорики. Система і структура східнослов'янських мов. 2015. Вип. 8. С. 86-95.

15. Клименко Н.Ф. Вияви категорії демінутивності в науковому стилі. Українська мова. 2017. № 2. С. 3-13.

\section{REFERENCES}

1. Kubryakova, E.S. (2004). Yazyk i znanie. Na puti polucheniya znaniya o yazyke: chasti rechi s kognitivnoj tochki zreniya. Rol' yazyka v poznanii mira [Language and knowledge. On the way of acquiring knowledge of language: parts of speech from a cognitive point of view. The role of language in the knowledge of the world]. Moscow.

2. Babina, L.V. (2003). Vtorichnaya reprezentaciya konceptov $\mathrm{v}$ yazyke [Secondary representation of concepts in language] : diss. ... dok. filolog. Tambov. $341 \mathrm{p}$.

3. Lakoff, Dzh. (2004). Zhenshchiny, ogon' i opasnye veshchi: Chto kategorii yazyka govoryat nam o myshlenii. [Women, Fire and Dangerous Things: What Categories of Language Tell Us About Thinking]. Moscow.

4. Fauconnier, G., Turner, M. (2002). The way we think: conceptual blending and the mind's hidden complexities. New York.

5. Kireeva, D.M. (2012). Proiskhozhdenie teorii konceptual'noj integracii [The origin of the theory of conceptual integration]. The world of science, culture, education. № 4 (35) P. 78-80.

6. Maslova, V.A. (2001). Lingvokul'turologiya [Linguoculturology] : study guide for students of higher educational institutions. Moscow: Publishing Center "Academy". 208 p.

7. Metafora: v yazyke i tekste. [Metaphor: in language and text]. Moscow : Nauka, 1988. $176 \mathrm{p}$.

8. Zhabotinskaya, S.A. (2011). Konceptual'naya metafora: procedura analiza dlya mnozhestvennyh dannyh [Conceptual metaphor: An analysis procedure for multiple data.]. Actual problems of mentalinguistics. P. 3-6.

9. Lakoff, Dzh., Dzhonson, M. (2004). Metafory, kotorymi my zhivem [The Metaphors We Live By]. Moskva.

10. Chudinov, A.P. (2001). Rossiya v metaforicheskom zerkale: kognitivnoe issledovanie politicheskoj metafory (1991-2000) [Russia in a Metaphorical Mirror: A Cognitive Study of Political Metaphor (1991-2000)] : monografiya. Ekaterinburg. 238 p.

11. Kravcova, Yu.V. (2014). Metaforicheskaya motivaciya i ee osnovnye tipy (na materiale russkoj hudozhestvennoj metaforiki) [ Metaphorical motivation and its main types (based on the material of Russian artistic metaphor)]. Scientific works. Series "Philology. Linguistics". Vol. 209. T. 221. Mikolaïv : P. 46-51.

12. Sutulina, L.G. (2016). Metaforichna model' real'ne-irreal'ne u narativnij strukturi ispans'kih romaniv spogadiv 20-21 stolittya [Metaphorical model of the real-unreal in the narrative structure of Spanish novels memoirs of the 20-21 century]: dis. ... cand. philologist. Kyiv, 223 p.

13. Kratkij slovar' kognitivnyh terminov (1996). [A short dictionary of cognitive terms]. Edited by E.S. Kubryakova / Moscow State University Publishing House. Moscow, 245 p.

14. Kravcova, Y.V. (2015). Metodologicheskie osnovy semantiko-kognitivnogo issledovaniya metaforiki [Methodological bases of semantic-cognitive research of metaphor]. System and structure of East Slavic languages. Vol. 8. P. 86-95.

15. Klimenko, N.F. (2017). Viyavi kategoriï deminutivnosti v naukovomu stili [Manifestations of categories of diminutiveness in the scientific style]. Ukrainian language. № 2. P. 3-13. 